\title{
Explore Cross-Selling, Up-Selling, and Sales Promotion to Increase the Sales Volume of PT. Pegadaian Cabang Brebes
}

\author{
Mas'adah Mas'adah, Ahmad Hanfan* \\ Faculty of Economics and Business Management Study Program Pancasakti Tegal University \\ *Correspondence author.Email: ahmadhanfan@yahoo.com
}

\begin{abstract}
The purpose of this study is to examine the effect of cross-selling, up-selling, and sales promotion on sales volume using partial and simultaneous variables. This research hypothesis states that (1) cross-selling has an effect on sales volume. (2) Upselling has an effect on sales volume. (3) sales promotion has an effect on sales volume. This study utilized primary data and a quantitative approach. The validity and reliability tests, the successive interval method test (MSI), the classic assumption test, multiple linear regression analysis, the t-test, the F test, and the coefficient of determination test are used to analyze the data. The findings of this study indicate that: (1) crossselling has a marginal effect on sales volume, with a significant value of 0.0170 .05 ; and (2) cross-selling has a marginal effect on sales volume. (2) Upselling has a negligible effect on the company's value, with a significant value of $0,621>0,05$. (3) sales promotion has a marginal effect on company value of $0,0090,05$.
\end{abstract}

Keywords: Cross-Selling, Up-Selling, Sales Promotion, Sales Volume

\section{INTRODUCTION}

Business competition is getting tighter, demanding companies to compete and set effective strategies. All companies, in general, have the primary goal of seeking profit by calling maximum profit from the sale of their products so that the company's survival can be maintained. To achieve these goals, strategies are needed to attract customers and prospective customers. [1] of lifestyles and patterns of society that are increasingly advanced, it provides opportunities for companies to create and offer a variety of products and services that suit the community's needs. [2,3]Companies must aggressively look for new ways to satisfy customers and add benefits to their offerings, which help customers and surprise and delight them.[2]

At this time, companies are competing to get customers, because of the variety of products or services, both in terms of number, type, brand, and service, so that the company must find ways so that customers can enjoy various alternative options without having to run to other competitors. Customers who are faced with a wide selection of products or services, in determining their choice they will choose the offer that is expected to provide the highest value. Today, many entrepreneurs and marketers spend a lot of the company budget to increase the sales of their products. In addition to looking for new consumers, there are other ways to improve the company's sales through old consumers. Gartner Group research [4] that $20 \%$ of $80 \%$ of a company's future profits come from old consumers.

Along with the company's products and services, various marketing strategies are carried out to attract as many customers as possible. [5] one of which is promotion, which is the activities undertaken by a business to educate, inform, persuade, and influence consumers to choose or purchase a product offered by the business.. The promotion expected the sales process to occur. Sales are contacts among people who meet in real life that demonstrate the ability to create, improve, master, or maintain profitable exchange relationships. Sales are also defined as efforts made by individuals or groups to deliver goods to those in need in exchange for money according to the price specified by mutual consent. According to[6], sales volume is the net sales of the company's earnings report. [7]Net sales are earned through the proceeds of sales of all products (product lines) over time, and sales proceeds are achieved 
from market share, a potential sale, which can consist of territorial groups and buyer groups over some time. $[8,9]$

PT. Pegadaian is one of the people's choices to pawn valuables to get funds faster, safer and younger. Pawn business guarantees valuables to obtain a certain amount of money and can be redeemed after a particular time, as one of the nonbank financial institutions in Indonesia, PT. Pegadaian, a business entity owned (SOE), has undergone a metamorphosis from time to time. PT. Pegadaian has proliferated into Indonesia's largest government-owned pawn company. [7]The vision of PT. Pegadaian is the most valuable financial company in Indonesia and is the best financial inclusion agent in the community.[10] Currently PT. Pegadaian have several products, namely:

a. The main products are KCA (kredit cepat aman), Krasida (gadai angsuran emas), Kreasi (kredit sistem fiduciary), and gadai effect.

b. Shariah products are rahn, arrum, arrum haji.

c. Gold Investment in the form of precious gold, gold savings, gold.

d. The product is pawnshop remittance, multi online payment.

\section{METHODS}

The type of research used in this research is quantitative research. Quantitative research methods, as proposed by [11], are based on quantitative data, whereas quantitative data is data in the form of numbers

According to $[6,12]$, associative research is research that aims to analyze the relationship or influence between more varieties, where this

Table 1. One-Sample Kolmogorov-Smirnov Test

\begin{tabular}{|c|c|c|}
\hline & $\begin{array}{l}\text { Unstandardiz } \\
\text { ed Residual }\end{array}$ \\
\hline \multicolumn{2}{|c|}{$\mathrm{N}$} & 38 \\
\hline \multirow{2}{*}{$\begin{array}{c}\text { Normal } \\
\text { Parameters } \\
\text { a,b }\end{array}$} & Mean & ,0000000 \\
\hline & Std. Deviation & 2,76894808 \\
\hline \multirow{3}{*}{$\begin{array}{c}\text { Most Extreme } \\
\text { Differences }\end{array}$} & Absolute &, 120 \\
\hline & Positive &, 120 \\
\hline & Negative &,- 101 \\
\hline \multicolumn{2}{|c|}{ Test Statistic } &, 120 \\
\hline \multicolumn{2}{|c|}{ Asymp. Sig. (2-tailed) } &, $183^{\mathrm{c}}$ \\
\hline \multicolumn{3}{|c|}{ a. Test distribution is Normal. } \\
\hline \multicolumn{3}{|c|}{ b. Calculated from data. } \\
\hline \multicolumn{3}{|c|}{ c. Lilliefors Significance Correction. } \\
\hline
\end{tabular}

method examines sales employee section by collecting internal data from the company concerned based on question questionnaire data that has been given directly to be filled out and collected will then be analyzed. The research variable is a limit to the definition of the variable studied. It already reflects the indicators used to measure the variable in question-Cross-selling, Up-selling, Promotion sales, and Sales volume.

\section{RESULT}

This research was based at PT. Pegadaian Branch Brebes Jalan Jenderal Sudirman No. 51 Brebes. The population inthiselitian comprises marketers, sales heads, marketing executives, staff marketing executives, business process outsourcing, relationship officer, cashier, unit manager, and branch leaders. A sample study is a study that uses a subset of the population as a data source and can be used to obtain a representative sample. In calculating the number of samples used in this study, the authors used a saturated sample method, which resulted in a total of 38 people. [6] Taken as a whole

\subsection{Multicollinearity Test}

The multicollinearity test tests whether regression models find correlations between independent variables. Correlations between independent variables should not occur in a good regression model. Multicolonierity can also be seen from the value of tolerance and variance inflation factor (VIF). Typically, a cutoff value of 0.10 or equal to the VIF value of 10 is used to indicate the presence of multicollinearity.

Table 2. Multicolonie

\begin{tabular}{|c|c|c|c|}
\hline \multicolumn{4}{|c|}{ Coefficients } \\
\hline \multirow{2}{*}{\multicolumn{2}{|c|}{ Type }} & \multicolumn{2}{|c|}{ Collinearity Statistics } \\
\hline & & Tolerance & VIF \\
\hline \multirow[t]{4}{*}{1} & (Constant) & & \\
\hline & Cross Sell &, 593 & 1,685 \\
\hline & Up_Sell & ,905 & 1,104 \\
\hline & Promotion &, 563 & 1,775 \\
\hline
\end{tabular}

Based on Tabel, the results of the multicollinearity test above showed all the variables used had a VIF value of $<10.00$ and a tolerance value of $>0.10$, so it can be concluded that there are no symptoms in this study multicollinearity in the regression model used. 


\subsection{Heterocedasticity Test}

Heteroskedasticity tests aim to test whether regression models are misaligned from residual or observational to other observations. If the variance from residual to comment remains then it is called homoskedastisity and if different is called heteroskedastisity.

Figure 1 Heteroskedasticity

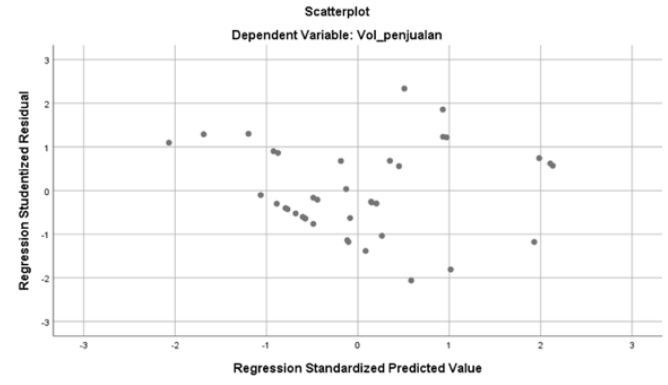

According to the output of the heteroskedasticity test, data processing with scatterplot graphs revealed that there was no discernible pattern of order and that the points were distributed above and below the Y axis value 0 . This implies that regression models are not heteroskedastic. So that the regression model is worth using for research with independent variables of cross selling, up selling and sales promotion with dependent variables of sales volume.

\subsection{Normality Test}

The normality test is used to determine whether confounding or residual variables in regression models have a normal distribution. Based on the results of the one-sample Kolmogorov-Smirnov test table above, the asymp value was obtained. Sig. (2tailed) by 0.183 . This is greater than the $\alpha$ of $0.183>$ 0.05 which indicates that the data isnormal distribution.

\subsection{Multiple Linear Regression Results}

Multiple regression analysis is used to forecast and determine the effect of independent variables on dependent variables, such as cross-selling, upselling, and sales promotion., namely sales volume. Here are the results of multiple regression analysis:

Tabel. 3 Multiple Regression

\begin{tabular}{|c|c|c|c|c|c|c|}
\hline \multicolumn{7}{|c|}{ Coefficients } \\
\hline \multirow{2}{*}{\multicolumn{2}{|c|}{ Type }} & \multicolumn{2}{|c|}{ Unstd Coe } & $\begin{array}{c}\text { Stand } \\
\text { Coef }\end{array}$ & \multirow[b]{2}{*}{$T$} & \multirow{2}{*}{$\begin{array}{l}S \\
i \\
g\end{array}$} \\
\hline & & $B$ & Error & Beta & & \\
\hline \multirow[t]{2}{*}{1} & (Constant) & 2,779 & 4,860 & &, 572 &, 571 \\
\hline & cross selling & ,315 &, 125 &, 375 & 2,517 &, 017 \\
\hline
\end{tabular}

\begin{tabular}{|c|c|c|c|c|c|c|}
\hline & up_selling &, 088 &, 177 &, 060 &, 499 &, 621 \\
\cline { 2 - 6 } & sales promotion &, 393 &, 141 &, 425 & 2,786 &, 009 \\
\hline
\end{tabular}

Based on the multiple regression table obtained the result of column $\mathrm{B}$ the constant value of 2.779; the value of the cross-selling coefficient 0.315 ; the value of the up-selling coefficient 0.088 and the value of the sales promotion coefficient 0.393 . The regression equation is:

Sales Volume $=2,779+0,315$ cross selling + 0,088 up selling +0.393 promosi sales + e. The meaning of this regression is:

The meaning of this regression is:

a) The constant value of 2,779 means that if cross selling $\left(\mathrm{X}_{1)}\right.$,up selling $\left(\mathrm{X}_{2}\right)$ and sales promotion $\left(\mathrm{X}_{3}\right)$ arezero, then the sales volume (Y) is worth 2,779.

b) The regression coefficient for cross selling to sales volume of 0.315 means that any increase in cross selling by $1 \%$ assuming other free variables remain will increase the sales volume by 0.315 . Conversely, if there is a decrease of $1 \%$ assuming other free variables remain it will decrease sales volume by 0.315 .

c) The regression coefficient for upselling of 0.088 means that each increase in up-selling by $1 \%$ assuming other free variables remain will increase sales volume by 0.088 . Conversely, if there is a decrease of $1 \%$ assuming other free variables remain it will decrease sales volume by 0.088 .

d) The regression coefficient for sales promotions of 0.393 means that each sales promotion increase of $1 \%$ assuming other free variables remain will increase sales volume by 0.393 . Conversely, if there is a decrease of $1 \%$ assuming other free variables remain it will decrease sales volume by 0.393 .

\subsection{Coefficient Determination Test (R2)}

The coefficient of determination (R2) essentially indicates how well a model can account for variation in independent variables. Between zero and one is the magnitude of the coefficient of determination. A low R2 value indicates that independent variables have a very limited ability to explain the variation of dependent variables. A value near one indicates 


\subsection{Statistical Test}

Independent variables contain almost all of the information necessary to forecast dependent variable variation.

Tabel. 4 Coefficient Dethermination

\begin{tabular}{|c|c|c|c|c|c|c|}
\hline \multirow{3}{*}{\multicolumn{2}{|c|}{ Type }} & \multicolumn{4}{|c|}{ Coefficients } & \multirow[b]{3}{*}{ Sig. } \\
\hline & & \multicolumn{2}{|c|}{$\begin{array}{c}\text { Unstand } \\
\text { Coeff }\end{array}$} & \multirow{2}{*}{$\begin{array}{c}\text { Stand Coeff } \\
\text { Beta }\end{array}$} & \multirow[b]{2}{*}{$T$} & \\
\hline & & $\mathrm{B}$ & \begin{tabular}{|c|} 
Std. \\
Error
\end{tabular} & & & \\
\hline \multirow[t]{4}{*}{1} & (Constant) & 2,779 & 4,860 & &, 572 &, 571 \\
\hline & cross_sellin & ,315 & ,125 & ,375 & 2,517 & 017 \\
\hline & up_selling & ,088 & , 177 & ,060 & ,499 & ,621 \\
\hline & $\begin{array}{l}\text { promosi_pe } \\
\text { njualan }\end{array}$ & ,393 & , 141 & ,425 & 2,786 & ,009 \\
\hline
\end{tabular}

Based on the table above the results of the ecoeffectiveness determination obtained the results of adjusted $R$ square of 0,514 or $51.4 \%$. The value can be inferred to mean that the value of $51.4 \%$ is the amount of variation value of the dependent variable of sales volume that can be explained by the relationship between independent variable crossselling, up-selling, and sales promotion together with sales volume. The remaining $48.6 \%$ was $6 \%$ by other variables not described in the study.

The statistical test $\mathrm{t}$ demonstrates how much influence a single explanatory or independent variable has on the variation of the dependent variable. Results of Tests, The statistical test $t$ quantifies the extent to which the influence of a single explanatory or independent variable has an effect on the variation of dependent variables.

Tabel. 5. Determination Coefficient

\begin{tabular}{|c|c|c|c|c|}
\hline & \multicolumn{4}{|c|}{ Model Summary } \\
\hline type & $R$ & $\begin{array}{c}R \\
\text { Squar } \\
e\end{array}$ & $\begin{array}{l}\text { Adjusted } R \\
\text { Square }\end{array}$ & $\begin{array}{l}\text { Std. Error of } \\
\text { the Estimate }\end{array}$ \\
\hline & $\begin{array}{l}, 744 \\
a\end{array}$ &, 553 &, 514 & 2,888526 \\
\hline & & $\begin{array}{l}\text { Prea } \\
\text { ons, }\end{array}$ & $\begin{array}{l}\text { s:(Consta } \\
\text { selling, c }\end{array}$ & $\begin{array}{l}\text { t), seller- } \\
\text { oss sellin }\end{array}$ \\
\hline
\end{tabular}

From the test tablet above obtained the following results:

a) The influence of cross-selling $\left(\mathrm{X}_{1)}\right.$ on sales volume at PT. Brebes branch pawnshop. From the calculation of the statistical test $t$ using SPSS obtained $\mathrm{t}$ count $=2.517$ greater than table $=$ $\mathrm{t}(\alpha / 2 ; \mathrm{n}-\mathrm{k}-1=\mathrm{t}(0.025: 28))=2.024$ with a significant value of 0.017 smaller than 0.05 then $\mathrm{H}_{0}$ rejected. Thus the conclusion of crossselling affects the volume of sales in PT. Brebes branch pawnshop.

b) The effect of up-selling (X2) on sales volume at PT. Pegadaian Cbrother Brebes. From the calculation of the statistical test $t$ using SPSS obtained $\mathrm{t}$ count $=0.499$ smaller than table $=\mathrm{t}$ $(\alpha / 2 ; \mathrm{n}-\mathrm{k}-1=\mathrm{t}(0.025: 28))=2.024$ with a significant value of 0.621 greater than 0.05 then $\mathrm{H}_{0}$ diterima. Thus the conclusion of upselling has no effect on the volume of sales in PT. Brebes branch pawnshop.

c) The effect of sales promotion $\left(\mathrm{X}_{3}\right)$ on sales volume at PT. Brebes branch pawnshop. From the calculation of the statistical test $t$ using SPSS obtained $\mathrm{t}$ count $=2.786$ greater than table $=$ $\mathrm{t}(\alpha / 2 ; \mathrm{n}-\mathrm{k}-1=\mathrm{t}(0.025: 28))=2.024$ with a significant value of 0.009 smaller than 0.05 then $\mathrm{H}_{0} \quad$ rejected. Thus, the conclusion of sales promotion affects the volume of sales in PT. Brebes branch pawnshop.

\section{CONCLUSIONS}

From the results of data analysis and hypothesis testing in this study, it can be concluded that, First Cross-Selling affects the sales volume of PT. Brebes Branch Pawnshop, was based on the $t$ (partial) test that has been done, obtained the results of the calculation of variable cross-selling is 2.517 and $t$ table 2.024, then $(2,517>2,024)$ and a significant value of $(0.017<0.05)$, meaning it partially affects sales volume. The findings of this study corroborate previous research conducted by [6] showed that cross-selling has a positive influence on sales volume.

Second, Upselling has no effect on sales volume. This is evidenced by the acquisition of the result of the value of $t$ calculated variable up selling is 0.449 and the value of $t$ table 2.024 , then $(0.449$ $<2.024)$ and significant value of $(0,621>0.05)$, meaning that up selling partially is not affect the volume of sales. This is because, not all customers want to increase the value of their loan even though loan to value (ltv) can still be raised, on the grounds of taking out a loan or buying a product according to their needs only. The results of this study are not in line with research conducted by [6] showing that up selling has a positive influence on the company's sales volume.

Third, Promosi sales distribution has a positive and significant effect on sales volume. This is 
evidenced by the acquisition of the results of the value of the sales promotion variable is 2,786 and the value of $t$ table 2.024 , then $(2,786>2.024)$ and a significant value of $(0.009<0.05)$, meaning promote sales partially affect sales volume. The results of this study are in line with research conducted by [6] showing that sales promotion has a positive influence on sales volume

\section{REFERENCES}

[1] Ndem S, Ezekial. The Impact Of Trade Promotion On Sales Volume In The Beer Industry. British Journal of Marketing Studies 2019;7:5771.

[2] Igo H, Rizal. Analisys Of Promotion In Increasing Sales Volume In PT. Hasjrat Abadi Perwakilan Unaaha. . International Journal of Education and Research 2019;7.

[3] Kotler P, Armstrong G. Principle Of Marketing. vol. 1. 1st ed. New York: Pearson Education Limited,; 2018.

[4] Mulyadi. Akuntansi Biaya. 5th ed. Yogyakarta: YKPN Yogyakarta; 2015.

[5] Askagarama. Upselling: Pengertian, Strategi dan Contohnya. vol. 1. 2019.

[6] Teece DJ, Pisano G, Shuen A. Dynamic Capabilities and Strategic Management. Strategic Management Journal 1997;18:509-33.

[7] Hadinata N, Kurniawan, Ramadanti Utami I. Implementasi Metode Up Selling Pada Sistem Informasi Penjualan. Jurnal Ilmiah MATRIK 2018;20:192-9.

[8] Chaerunnisa S, Daniel Samboh R. Pentingnya Upsellingdi Reservation Section Front Office Department Dalam Meningkatkan Pendapatan Kamar Di Hotel X Jakarta. Eduturisma 2019;4:65-72.

[9] Jeffery R. Cashi. Implementation Of A Cross-Selling Strategy For A Large Midwestern Health Care Equipment Company. 2002.

[10] Kuswardani DC, Wibisono Nt. Strategic Role Of Sales Promotion In Increasing The Number Of Vermox Drug Sales. Economics \& Business Solutions Journal 2018;2:1-7.
[11] Arinkunto S. Prosedur Penelitian Suatu Pendekatan Praktik. JAKARTA: Rineka Cipta; 2006.

[12] Sugiyono. Sugiyono, Metode Penelitian Kuantitatif Kualitatif Dan R\&D. Bandung: ALFABETA; 2012. 